Boletín de la Sociedad Geológica Mexicana

VOLUMEN 65, NÚM. 2, 2013, P. 249-254

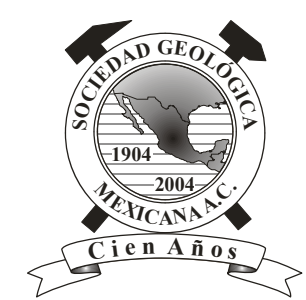

\title{
A new Middle Jurassic (Bajocian) homolodromioid crab from northwest France; the earliest record of the Tanidromitidae
}

\author{
René H. B. Fraaije ${ }^{1, *}$, Barry W. M. van Bakel ${ }^{1,2}$, Danièle Guinot ${ }^{3}$, John W. M. Jagt ${ }^{4}$ \\ ${ }^{1}$ Oertijdmuseum De Groene Poort, Bosscheweg 80, NL-5283 WB Boxtel, the Netherlands. \\ ${ }^{2}$ Naturalis Biodiversity Center, P.O. Box 9517, NL-2300 RA Leiden, the Netherlands. \\ ${ }^{3}$ Département Milieux et peuplements aquatiques, Muséum national d'Histoire naturelle, 61 rue Buffon, CP 53, F-75231 Paris Cedex \\ 5, France. \\ ${ }^{4}$ Natuurhistorisch Museum Maastricht, de Bosquetplein 6-7, NL-6211 KJ Maastricht, the Netherlands. \\ *info@oertijdmuseum.nl
}

\begin{abstract}
A new homolodromioid, Tanidromites maerteni, the earliest member of the genus and family, is recorded from the lower upper Bajocian (Niortense Zone) of Calvados, northwest France. It is noted that carapace morphologies of other Jurassic brachyuran taxa within the family Prosopidae are closely similar to those of tanidromitids, and that diagnoses of recently erected Jurassic families and genera partially overlap or have conflict among them. Thus, the taxonomy of the earliest brachyuran groups appears to be less stable than currently thought. In recent years, knowledge of primitive extinct brachyurans has greatly benefitted from findings made by amateur collectors, the present paper included.
\end{abstract}

Keywords: Crustacea, Homolodromioida, Tanidromitidae, Middle Jurassic, France, new species.

\section{Resumen}

Se reporta un nuevo homolodromioideo, Tanidromites maerteni, el miembro más antiguo del género y la familia, para la parte inferior del Bajociano superior (Zona Niortense) de Calvados, noroeste de Francia. Se hace notar que las morfologías del caparazón de otros taxa de braquiuros del Jurásico de la familia Prosopidae son muy similares a las de los tanidromítidos, y que las diagnosis de familias y géneros del Jurásico recientemente propuestas parcialmente se sobrelapan o crean conflicto. Por lo tanto, parece ser que la taxonomía de los grupos primitivos de braquiuros es menos estable de lo que se cree. En años recientes, el conocimiento de los braquiuros primitivos extintos se ha visto muy beneficiado por los hallazgos realizados por colectores aficionados, siendo el presente trabajo un ejemplo.

Palabras Clave: Crustacea, Homolodromioida, Tanidromitidae, Jurásico Medio, Francia, nueva especie. 


\section{Introduction}

With a delay of more than a decade, the PhD dissertation by Wehner (1988) sparked a renewed interest in Jurassic brachyurans, and a plethora of papers on the taxonomy, phylogenetics and paleoecology of these taxa has appeared in recent years (e.g., Müller et al., 2000; Schweigert, 2006; Schweitzer et al., 2007; Krobicki and Zatoń, 2008; Schweitzer and Feldmann, 2008a, 2008b, 2009a, 2009b, 2010; Crônier and Boursicot, 2009; Hyžný et al., 2011; Starzyk et al., 2011, 2012). The family Tanidromitidae, erected by Schweitzer and Feldmann (2008a), currently comprises two genera, namely Gabriella Collins, Ross, Genzano and Mianzan, 2006 and Tanidromites Schweitzer and Feldmann, 2008a. Seven species have been assigned to the genus Tanidromites, which ranges from the upper Bajocian to the Tithonian (Schweitzer and Feldmann, 2008a, 2009b), with records from England, France, Germany, Switzerland, Austria, the Czech Republic, Poland, Romania and Lithuania (e.g., Schweitzer and Feldmann, 2009b; Hyžný et al., 2011; Schweigert and Koppka, 2011); we here add the eighth, Tanidromites maerteni $\mathrm{n}$. sp. Some undescribed species of Tanidromites have also been recorded from the Tithonian (uppermost Jurassic) of Ernstbrunn (Austria) and Štramberk (Czech Republic) by Schweitzer and Feldmann (2009b). For a detailed overview of all known representatives of the genus Tanidromites, reference is made to Hyžný et al. (2011, p. 3, table 1).

The holotype of Tanidromites richardsoni (Woodward, 1907) stems from the Anabacia Limestone (Clypeus Grit) of the southern Cotswolds, England (Withers, 1951). According to Hunter and Underwood (2009), this unit is of earliest Bathonian (Middle Jurassic) age. Two additional specimens of the same species were recorded from the Upper Coral Beds (Parkinsoni Zone, Truellei Subzone; upper upper Bajocian) of Somerset (England) by Withers (1951) and Donovan (1962), respectively . Recently, Schweigert and Koppka (2011) have described another specimen of $T$. richardsoni from coeval levels (Sengenthal Formation, Parkinsonien-Oolith Member) at Göllersreuth near Thalmässing (southern Germany).

The only other Middle Jurassic species, Gabriella lugobaensis (Förster, 1985), originates from reefal limestones near the top of the Lugoba Formation, as exposed two kilometres southeast of Lugoba, northern Tanzania. Although a number of ammonites held typical of the lower Bajocian Sauzei-Humphresianum Zone were recorded by Kapilima (2003b) from the middle part of the Lugoba Formation, the same author (Kapilima, 2003a) dated the reefal limestones near the top of the unit as Bathonian.

The present specimen, collected by Lionel Maerten (October 2, 2010) from the oolitic limestones locally called "Oolithes ferrugineuses de Bayeux" in the Commune de Maizet, Calvados (northwest France), is of early late Bajocian (Niortense Zone) age and thus constitutes the earliest record of the genus Tanidromites and of the family
Tanidromitidae.

\section{Systematic paleontology}

Order Decapoda Latreille, 1802

Infraorder Brachyura Latreille, 1802

Section Podotremata Guinot, 1977

Subsection Dromioidia De Haan, 1833

Superfamily Homolodromioidea Alcock, 1900

Family Tanidromitidae Schweitzer and Feldmann, 2008a

Genus Tanidromites Schweitzer and Feldmann, 2008a

Type species. Prosopon insigne von Meyer, 1857, by original designation

Tanidromites maerteni $\mathrm{n}$. sp.

Figure 1

\subsection{Material examined}

The holotype, and sole specimen known to date, is MNHN.F.A47612 (leg. L. Maerten) in the collections of the Muséum National d'Histoire Naturelle, Département Histoire de la Terre (Paris).

\subsection{Etymology}

In honor of Lionel Maerten, who collected the holotype and kindly donated it to the MNHN collections.

\subsection{Type locality and stratigraphy}

The type specimen originates from the town quarry of the Commune de Maizet, Calvados (northwest France) from a level which is locally referred to as the "Oolithes ferrugineuses de Bayeux", the age of which is early late Bajocian (Niortense Zone) (Gauthier et al., 1996).

Table 1. Ammonite zones of the upper Bajocian (after Callomon, 2003).

\begin{tabular}{cl}
\hline Zones & \multicolumn{1}{c}{ Subzones } \\
\hline \multirow{3}{*}{ Parkinsoni } & Bomfordi \\
& Truellei \\
& Acris \\
& Tetragona \\
Garantiana & Garantiana \\
& Dichotoma \\
& Baculata \\
Niortense & Polygyralis \\
& Banksii \\
\hline
\end{tabular}




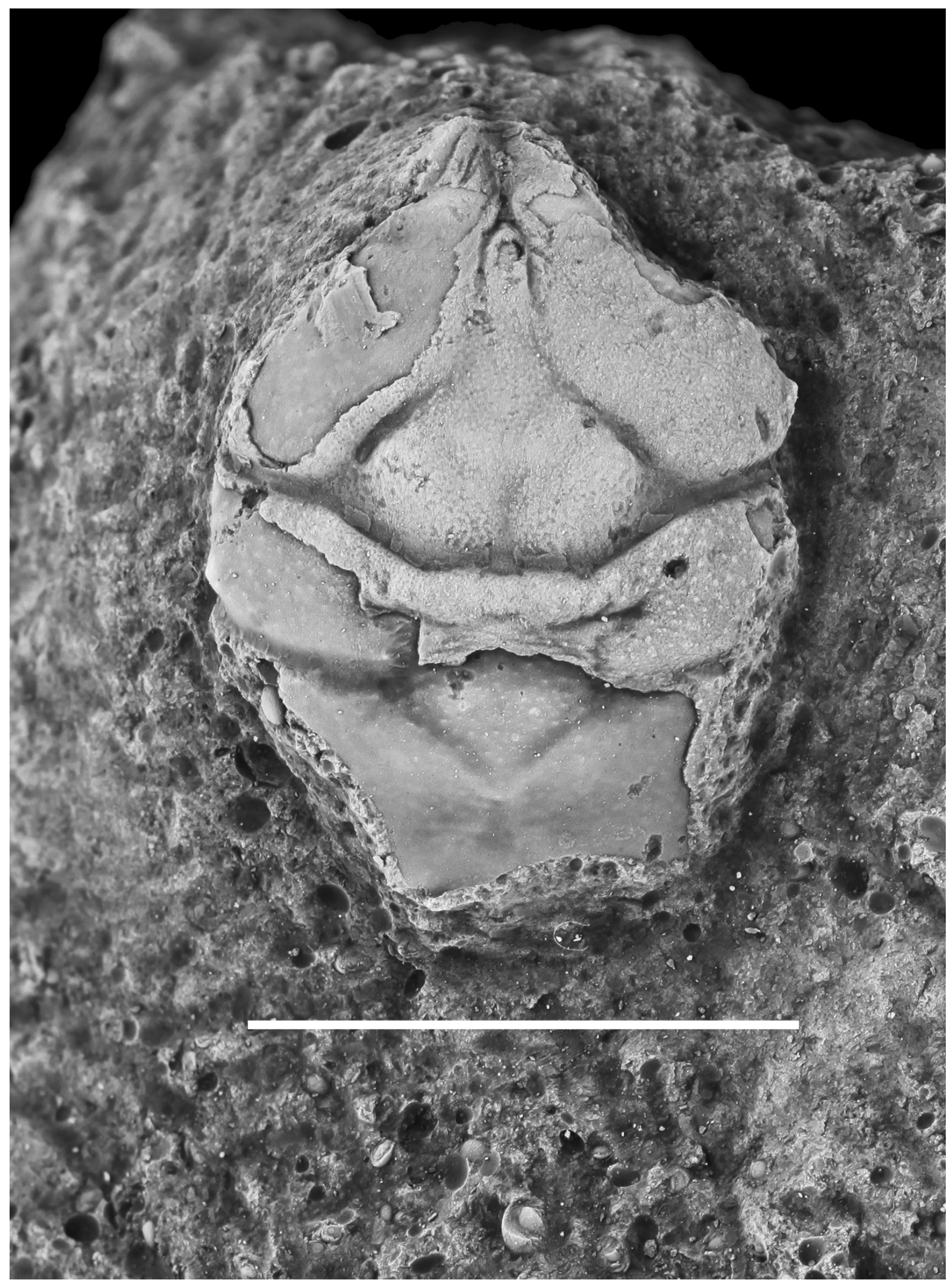

Figure 1. Tanidromites maerteni $\mathrm{n}$. sp. with a maximum length of $14 \mathrm{~mm}$, a maximum height of $4 \mathrm{~mm}$ and a maximum width of $11 \mathrm{~mm}$, measured across epibranchial region. Scale bar $=1 \mathrm{~cm}$. 


\subsection{Diagnosis}

A tanidromitid with lateral epibranchial spine, a slightly concave portion of the cervical groove at the central posterior margin of the mesogastric region; two faint, yet clearly visible, $\mathrm{V}$-shaped grooves on the central part of the mesogastric region; relatively deep and long postcervical grooves; pustulate ornament on cardiac, epibranchial and epigastric regions.

\subsection{Description}

Carapace rectangular in outline with a maximum length of $14 \mathrm{~mm}$, a maximum height of $4 \mathrm{~mm}$ and a maximum width of $11 \mathrm{~mm}$, measured across epibranchial region. Strongly vaulted in longitudinal and transverse sections. Broad-based triangular rostrum, downturned, with median sulcus. Orbits and orbital sockets not preserved, but weak rim present. Mesogastric region well defined, widening considerably posteriorly with a faint median sulcus on the posterior part and two faint, V-shaped sulci medially, in parallel arrangement. Pronounced cervical groove, slightly concave medially and sinuous towards the lateral sides, which incises it distinctly. Inflated urogastric region posteriorly bordered by relatively long and distinct postcervical grooves. Distinct epibranchial region in between deeply incisive cervical and branchiocardiac grooves with lateral epibranchial spine in posterior part. Cardiac region pentagonal. Ornament pustulate on all inflated regions, but most pronounced on epigastric and cardiac regions. Appendages, ventral side and abdomen not preserved.

\subsection{Remarks}

Tanidromites maerteni $\mathrm{n}$. sp. differs from all other members of the genus in possessing a lateral epibranchial spine; the central base of the mesogastric region is slightly concave, whereas all other species show a more V-shaped cervical groove medially and the mesogastric region has two highly inflated lateral parts and two V-shaped sulci medially; in addition, the pronounced postcervical grooves are the longest within the genus.

Lately, it has become clear to us that the various published diagnoses of the family Tanidromitidae are insufficient to differentiate assigned species from those placed in Prosopidae von Meyer, 1860. Schweitzer and Feldmann (2008a) originally mentioned that the carapace was longer than wide. Subsequently, Schweitzer and Feldmann (2009b, p. 2) stated "width 70-85\% maximum length". The specimen described by Schweigert and Koppka (2011, p. 5, fig. 5) as T. richardsoni has a greater $\mathrm{L} / \mathrm{W}$ ratio, and eventhough the rectangular carapace and groove pattern clearly match the Tanidromitidae, that particular specimen could not be assigned to the family if the emended diagnoses were strictly adopted. The most recent, adjusted diagnosis of the family Tanidromitidae, by Schweitzer and Feldmann (2009b, p. 2) is as follows, "Carapace longer than wide, width $70-85 \%$ maximum length; lateral flanks of carapace strongly developed; regions well-defined, generally smooth, protogastric and hepatic regions confluent; rostrum downturned, blunt-triangular, axially sulcate; orbit small, directed forward, situated at base of rostrum, rimmed; augenrest usually rimmed, may have small spines or protuberances; fronto-orbital width 50-60 \% maximum carapace width; lateral margins parallel, subparallel to one another, or diverging slightly posteriorly; subhepatic region may be markedly inflated; large portion of ventral side lies below ventral extension of branchiocardiac groove; ventral extension of cervical groove deep; ventral extension of branchiocardiac groove diminishing ventrally."

The diagnosis of the family Prosopidae (see Schweitzer and Feldmann, 2009a, p. 65) is, "Carapace longer than wide, narrowing anteriorly, widest at branchial regions; regions well defined by grooves; cervical and branchiocardiac groove well developed; postcervical groove usually present; rostrum extending well beyond orbits; augenrest directed anterolaterally, bounded by inflated subhepatic region on suborbital rim and inner- and outer-orbital spine on upperorbital margin; lateral margins well defined but not high; grooves deep and well marked, postcervical groove present; posterior margin bi-convex, apparently to accommodate fifth pereiopods." Thus, the only difference at the family level between Tanidromitidae and Prosopidae that can be used is the presence of a biconvex posterior margin in the latter. However, Schweitzer and Feldmann (2008b) included the genus Laeviprosopon in Prosopidae, despite the fact that they failed to document a biconvex posterior margin in both their diagnosis and illustrations. In short, in the current diagnoses of both families there are no unambiguous diagnostic differences.

The specimen described by Schweigert and Koppka (2011) as T. richardsoni differs from both the type species and from T. maerteni $\mathrm{n}$. sp. in showing a much greater $\mathrm{L} / \mathrm{W}$ ratio, in the shape of the cardiac region and shape and location of the postcervical groove. The former is a relatively small specimen and care should be taken to include L/W ratios in diagnoses of families, so long as little is known about ontogenetic developments of the species included. Considerable ontogenetic variation within Goniodromitidae has recently been demonstrated by Klompmaker et al. (2012) for several species from the Albian-Cenomanian (middle Cretaceous) of Koskobilo, northern Spain. Length/ width ratios vary, with smaller specimens being relatively longer, more vaulted longitudinally and transversely, and showing a tendency towards a more triangular rostrum and more obscured ornament. Most Jurassic specimens lack their shell or large portions of it. In the diagnoses of Tanidromitidae by Schweitzer and Feldmann (2008a, p. 137; 2009b, p. 2), it reads, "regions mostly/generally smooth". Schweigert and Koppka (2011) already noted that care should be taken in the case of internal moulds, because a new specimen of Tanidromites sculpta (Quenstedt, 1857) 
did show a strong ornament, while all internal moulds of the same species were entirely smooth. It appears that most species of both Tanidromites and Gabriella did have pustulose, granulose and/or scabrous ornamented carapace regions. The holotype of Tanidromites maerteni $\mathrm{n}$. sp. demonstrates both the internal mould and portions of cuticle; this clearly shows the difference in ornament.

Unfortunately, our study could not benefit from data presented by Krobicki and Zatoń (2008), because those authors did not provide any photographs or discuss any morphological details in their survey of the most diverse mid-Jurassic brachyuran fauna so far, with one new genus and four new species noted. It can only be hoped that these data will become available in the very near future.

\section{Acknowledgements}

We thank Dr. Sylvain Charbonnier for providing stratigraphic data and Mr Philippe Richir for a cast of the specimen (both Muséum National d'Histoire Naturelle, Département Histoire de la Terre, Paris); also to Mr. Lionel Maerten (Ver-sur-Mer, France) for donating the specimen. Thanks are due to Dr. Francisco Vega (Instituto de Geología, UNAM, Mexico), and an anonymous reviewer for their comments and improvements of an earlier typescript.

\section{References}

Alcock, A., 1900, Materials for a carcinological fauna of India, 5: The Brachyura Primigenia or Dromiacea: Journal of the Asiatic Society of Bengal, 68, II/3, 123-169.

Callomon, J.H., 2003, The Middle Jurassic of western and northern Europe: its subdivisions, geochronology and correlations: Geological Survey of Denmark and Greenland Bulletin, 1, 61-73.

Collins, J.S.H., Ross, A.J., Genzano, G., Mianzan, H., 2006, Earleria gen. nov. \& Gabriella gen. nov., replacement names for Foersteria Arai \& Brinckmann-Voss, 1980 (Cnidaria, Hydrozoa, Mitrocomidae) and Foersteria Wehner, 1988 (Crustacea, Decapoda, Prosopidae), junior homonyms of Foersteria Szepligeti, 1896 (Insecta, Hymenoptera, Braconidae): Bulletin of the Mizunami Fossil Museum, 33, 125-126.

Crônier, C., Boursicot, P.-Y., 2009, A new decapod crustacean faunule from the Middle Jurassic of north-west France: Palaeontology, 52, 1275-1289.

De Haan, W., 1833-1850, Crustacea, in: von P. F. Siebold, Fauna Japonica sive descriptio animalium, quae in Itinere per Japoniam, Jussu et auspiciis superiorum, qui Summun in India Batava Imperium tenent, suscepto, annis 1823-1830 collegit, notis, observationibus et adumbrationibus illustravit, pp. i-xvii_i-xxxi_ix-xvi_1-243, pls. A-J_L-Q_1-55, Ludguni-Batavorum

Donovan, D.T., 1962, New examples of the fossil crab Pithonoton from the Inferior Oolite of Gloucestershire and Somerset: Proceedings of the Geologists' Association, 73(2), 193-196.

Förster, R., 1985, Frühe Anomuren und Brachyuren (Decapoda, Crustacea) aus dem mittleren Dogger: Mitteilungen der Bayerischen Staatssammlung für Paläontologie und historische Geologie, 25, 45-60.

Gauthier, H., Rioult, M., Trévisan, M., 1996, Répartition biostratigraphique des ammonites dans l'Oolithe ferrugineuse de Bayeux (Bajocien) à Feuguerolles-sur-Orne (Calvados). Eléments nouveaux pour une révision des Garantianinae: Géologie de la France, 2, 27-67.
Guinot, D., 1977, Propositions pour une nouvelle classification des Crustacés Décapodes Brachyoures: Comptes rendus hebdomadaires des séances de l'Acade'mie des sciences, série D 285, 1049-1052.

Hunter, A.W., Underwood, C.J., 2009, Palaeoenvironmental control on distribution of crinoids in the Bathonian (Middle Jurassic) of England and France: Acta Palaeontologica Polonica, 54, 77-98.

Hyžný, M., Schlögl, J., Krobicki, M., 2011, Tanidromites insignis (von Meyer, 1857) (Crustacea: Decapoda: Brachyura) from Late Jurassic non-biohermal facies of the Western Tethys (Pieniny Klippen Belt, Western Carpathians, Slovakia): Neues Jahrbuch für Geologie und Paläontologie Abhandlungen, 262, 213-226.

Kapilima, S., 2003a, Tectonic and sedimentary evolution of the coastal basin of Tanzania during the Mesozoic times: Tanzania Journal of Science, 29, 1-16.

Kapilima, S., 2003b, Bajocian ammonites from Msata Hill (Lugoba Formation) in the hinterland of Dar es Salaam, Tanzania: Tanzania Journal of Science, 29, 35-42.

Klompmaker, A.A., Feldmann, R.M., Schweitzer, C.E., 2012, A hotspot for Cretaceous goniodromitids (Decapoda: Brachyura) from reef associated strata in Spain: Journal of Crustacean Biology, 32, 780-801.

Krobicki, M., Zatoń, M., 2008, Middle and Late Jurassic roots of brachyuran crabs: palaeoenvironmental distribution during their early evolution: Palaeogeography, Palaeoclimatology, Palaeoecology, 263, 30-43.

Latreille, P.A., 1802, Histoire naturelle, générale et particulière des Crustacés et des Insectes: Ouvrage faisant suite à l'histoire naturelle générale et particulière, composée par Leclerc de Buffon, et rédigée par C.S. Sonnini, membre de plusieurs sociétés savantes: In Familles naturelles des genres, 3, 13-467.

Meyer, H. von, 1857, Briefliche Mittheilungen, an Prof. Bronn gerichtet: Neues Jahrbuch für Mineralogie, Geognosie, Geologie und Petrefaktenkunde, 1857, 556.

Meyer, H. von, 1860, Die Prosoponiden oder die Familie der Maskenkrebse: Palaeontographica, 7, 183-222.

Müller, P., Krobicki, M., Wehner, G., 2000, Jurassic and Cretaceous primitive crabs of the family Prosopidae (Decapoda: Brachyura) - their taxonomy, ecology and biogeography: Annales Societatis Geologorum Poloniae, 70, 49-79.

Quenstedt, F.A., 1857, Der Jura: Tübingen, Germany, Laupp, 842 pp.

Schweigert, G., 2006, A specimen of Prosopon hebes v. Meyer, 1840 (Decapoda: Brachyura: Prosopidae) from the Middle Jurassic of SW Germany: Neues Jahrbuch für Geologie und Paläontologie Monatshefte, 2006, 361-370.

Schweigert, G., Koppka, J., 2011, Decapods (Crustacea: Brachyura) from the Jurassic of Germany and Lithuania, with descriptions of new species of Planoprosopon and Tanidromites: Neues Jahrbuch für Geologie und Paläontologie Abhandlungen, 260, 221-235.

Schweitzer, C.E., Feldmann, R.M., 2008a, A new classification for some Jurassic Brachyura (Crustacea: Decapoda: Brachyura: Homolodromioidea): families Goniodromitidae Beurlen, 1932 and Tanidromitidae, new family: Palaeobiodiversity and Palaeoenvironments, 87, 119-156.

Schweitzer, C.E., Feldmann, R.M., 2008b, Revision of the genus Laeviprosopon Glaessner 1933 (Decapoda: Brachyura: Homolodromioidea: Prosopidae) including two new species: Neues Jahrbuch für Geologie und Paläontologie Abhandlungen, 250, 273-285.

Schweitzer, C.E., Feldmann, R.M., 2009a, Revision of the Prosopinae sensu Glaessner, 1969 (Crustacea: Decapoda: Brachyura) including four new families, four new genera, and five new species: Annalen des Naturhistorischen Museums in Wien, 110A, 55-121.

Schweitzer, C.E., Feldmann, R.M., 2009b, Revision of Gabriella Collins et al., 2006 (Decapoda: Brachyura: Homolodromioidea: Tanidromitidae) with new Jurassic species: Neues Jahrbuch für Geologie und Paläontologie Abhandlungen, 252, 1-16.

Schweitzer, C.E., Feldmann, R.M., 2010, The oldest Brachyura (Decapoda: Homolodromioidea: Glaessneropsoidea) known to date (Jurassic): Journal of Crustacean Biology, 30, 251-256. 
Schweitzer, C.E., Feldmann, R.M., Lazăr, I., 2007, Decapods from Jurassic (Oxfordian) sponge megafacies of Dobrogea, Romania and reconsideration of Nodoprosopon Beurlen, 1928: Neues Jahrbuch für Geologie und Paläontologie Abhandlungen, 244, 99-113.

Starzyk, N., Krzemińska, E., Krzemiński, W., 2011, Intraspecific variation in the Jurassic crab Bucculentum bucculentum (Decapoda: Homolodromioidea: Bucculentidae): Neues Jahrbuch für Geologie und Paläontologie Abhandlungen, 260, 203-210.

Starzyk, N., Krzemińska, E., Krzemiński, W., 2012, A new crab species from the Oxfordian of Poland (Decapoda: Brachyura: Goniodromitidae): Neues Jahrbuch für Geologie und Paläontologie Abhandlungen, 263, 143-153.

Wehner, G., 1988, Über die Prosoponiden (Crustacea, Decapoda): Munich, Fakultät für Geowissenschaften der Ludwig Maximilians Universität zu München, $\mathrm{PhD}$ thesis, $154 \mathrm{p}$.
Withers, T.H., 1951, Some Jurassic and Cretaceous crabs (Prosoponidae): Bulletin of the British Museum (Natural History), Geological Series, 1(6), 171-186.

Woodward, H., 1907, On a new brachyurous Crustacean from the "ClypeusGrit" (Inferior Oolite) of the Cotteswold Hills: Geological Magazine (Decade V), 4, 79-81.

Manuscript received: September 28, 2012.

Corrected manuscript received: October 20, 2012.

Manuscript accepted: October 22, 2012. 